\title{
SEHAT DAN CERDAS DI MASA PANDEMI COVID-19 PADA YAYASAN KAFILATUR ROSUL PAMULANG TANGERANG SELATAN - BANTEN
}

\author{
Andi Nur Rahman'), Nina Valentika ${ }^{2)}$, NurulLita Sari ${ }^{3)}$, Nanik Ida Rosini ${ }^{4)}$, \\ Nunung Kusdaniyama', Mardianis ${ }^{6)}$, Muchamad Amirudin ${ }^{7}$, Yulis Setiani ${ }^{8}$, \\ Nanda Putri ${ }^{9)}$ \\ 1,2,3,4,5,6,7,8,9 Program Studi Matematika, Fakultas MIPA, Universitas Pamulang
}

\begin{abstract}
Abstrak
Kegiatan Pengabdian Kepada Masyarakat (PKM) merupakan salah satu tugas pokok dan sarana bagi dosen untuk berkontribusi pada masyarakat. Salah satu elemen masyarakat adalah Yayasan Kafilatur Rosul bertempat di Jalan Benda Timur 7 Blok F No 32 Pamulang 2 Tangerang Selatan - Banten memiliki anak binaan yang bersekolah mulai dari tingkat Sekolah Dasar sampai dengan Sekolah Menengah Atas dimana pada masa pandemi ini mereka harus menjalani kegiatan belajar mengajar secara daring atau online sehingga pemahaman mengenai materi pelajaran pun kurang khususnya pada mata pelajaran matematika. Dan di masa pandemi COVID-19 ini anak - anak binaan Yayasan Kafilatur Rosul juga membutuhkan penjelasan dan pemahaman mengenai cara pencegahan dari virus ini dan melaksanakan protokol kesehatan dengan baik dan benar sehingga mereka tetap terjaga kesehatannya. Sehingga solusi yang ditawarkan adalah memberikan edukasi mengenai kesehatan (mencuci tangan yang benar, melaksanakan protokol kesehatan dan pengetahuan tentang COVID-19), edukasi mengenai ilmu matematika yang digunakan dalam kehidupan sehari - hari, serta penyampaian materi matematika kelas 1 SMP (himpunan dan aljabar) memuat cara cepat dan tepat dalam menyelesaikan persoalan matematika khususnya pada materi himpunan dan aljabar. Kegiatan pengabdian kepada masyarakat ini dilaksanakan dari hari Kamis tanggal 5 November 2020 sampai dengan hari Sabtu tanggal 7 November 2020 dengan waktu penyampaian materi mulai dari pukul 09.00 WIB sampai dengan pukul 12.00 WIB. Pelaksanaan kegiatan pengabdian kepada masyarakat ini pun dilaksanakan dengan dua cara yaitu melalui daring (zoom) dan tatap muka langsung demi menjaga dan melaksanakan protokol kesehatan di tempat pengabdian kepada masyarakat tersebut.
\end{abstract}

Kata Kunci: Sehat, Cerdas, Matematika, Protokol Kesehatan

\begin{abstract}
Community Service Activities (PKM) are one of the main tasks and means for lecturers to contribute to society. One of the elements of society is the Kafilatur Rosul Foundation which is located at Jalan Benda Timur 7 Blok F No 32 Pamulang 2 Tangerang Selatan - Banten, who have assisted children who attend school from elementary to high school level where during this pandemic they have to undergo teaching and learning activities. online or online so that understanding of the subject matter is lacking, especially in mathematics. And during the COVID19 pandemic, the children assisted by the Kafilatur Rosul Foundation also need an explanation and understanding of how to prevent this virus and implement health
\end{abstract}


protocols properly and correctly so that they are maintained in good health. So that the solution offered is to provide education about health (washing hands properly, implementing health protocols and knowledge about COVID-19), education on mathematics used in everyday life, and delivery of mathematics material for grade 1 in junior high school (assemblies and algebra) contains a fast and precise way of solving math problems, especially on set and algebraic material. This community service activity is carried out from Thursday 5 November 2020 to Saturday 7 November 2020 with material delivery times starting from $09.00 \mathrm{WIB}$ to $12.00 \mathrm{WIB}$. The implementation of this community service activity is also carried out in two ways, namely through online (zoom) and face to face in order to maintain and implement health protocols at the community service place.

Keywords: Healthy, Intelligent, Mathematics, Health Protocol

Correspondence author: Andi Nur Rahman, dosen00700@unpam.ac.id, South Tangerang, Indonesia

\section{PENDAHULUAN}

Kegiatan Pengabdian Kepada Masyarakat (PKM) adalah salah satu dari tugas pokok yang harus dilaksanakan oleh dosen. Salah satu sarana bagi dosen untuk berkontribusi pada masyarakat adalah kegiatan PKM yang sesuai dengan bidang keilmuan. Dosen perlu mengetahui materi yang dibutuhkan dan relevan dengan kebutuhan masyarakat pada umumnya. Masyarakat yang dimaksud adalah pengguna matematika yaitu siswa atau anak yang masih mengeyam pendidikan di tingkat sekolah dasar dan menengah. Salah satu elemen masyarakat adalah Yayasan Kafilatur Rosul bertempat di Jalan Benda Timur 7 Blok F No 32 Pamulang 2 Tangerang Selatan Banten memiliki anak binaan yang bersekolah mulai dari tingkat Sekolah Dasar sampai dengan Sekolah Menengah Atas.

Salah satu mata mata pelajaran pada Sekolah Dasar, Sekolah Menengah Pertama dan Sekolah Menengah Atas adalah matematika. Pada umumnya, matematika merupakan mata pelajaran yang sangat ditakuti dan dijauhi oleh siswa. Faktor - faktor yang menyebabkan mata pelajaran matematika tersebut ditakuti atau dijauhi oleh siswa antara lain adalah metode pembelajarannya yang kurang menyenangkan, kurangnya alat peraga dalam pembelajaran matematika, guru yang menyampaikan terlihat menakutkan, materi matematika yang terlalu sulit dipahami, dan masih banyak lagi faktor-faktor lainnya.

Siswa perlu mengetahui kegunaan matematika dalam kehidupan sehari - hari agar mereka termotivasi dalam pembelajaran matematika, serta siswa memerlukan pemahaman konsep matematika dan cara singkat dalam menyelesaikan permasalahan matematika, khususnya dalam masa pandemi COVID-19 dimana siswa tidak mendapatkan penjelasan secara langsung atau utuh dari guru dikarenakan pembelajaran dilakukan secara daring atau online. Rata - rata siswa diberikan materi dan harus memahami materi itu sendiri, sedangkan untuk materi matematika itu agar siswa memahami materi tersebut maka materi itu harus disampaikan melalui lisan, tulisan dan siswa melakukan atau mencoba menyelesaikan masalah pada materi tersebut.

Semua aspek masyarakat termasuk anak - anak binaan Yayasan Kafilatur Rosul di masa pandemi COVID-19 ini harus mengetahui pentingnya manfaat protokol kesehatan 
demi menjaga kesehatan kita semua dan memutus mata rantai penyebaran COVID-19 ini, serta masyarakat juga harus mengetahui sanksi - sanksi atas pelanggaran protokol kesehatan ini agar dimaksudkan masyarakat patuh atas ketetapan pemerintah dalam mengatasi pandemi ini. Oleh karena itu masyarakat perlu diberikan edukasi atau pendidikan mengenai protokol kesehatan demi membantu pemerintah memutus mata rantai penyebaran virus ini. Seluruh elemen masyarakat yang paham tentang protokol kesehatan ini diharapkan dapat membantu pemerintah untuk mensosialisasikannya kepada masyarakat. Salah satu elemen masyarakat tersebut adalah Universitas Pamulang.

Universitas Pamulang (UNPAM) merupakan kampus yang berdiri di bawah naungan Yayasan Sasmita Jaya yang beralamat di Jl. Surya Kencana No. 1 pamulang dengan mengemban visi "Bermutu dalam pengembangan pendidikan, penelitian, dan pengabdian terjangkau seluruh lapisan masyarakat, berlandaskan ridha tuhan yang maha esa". Universitas Pamulang (UNPAM) dalam lingkup perguruan tinggi ada di dalam wilayah lingkungan Lembaga Layanan Pendidikan Tinggi (LLDIKTI) Wilayah IV.

Universitas Pamulang (UNPAM) membuka diri untuk melakukan berbagai kerjasama dengan berbagai pihak dalam rangka pengembangan ilmu, institusi, teknologi dan seni dalam rangka pelaksanaan Tri Dharma Perguruan Tinggi yakni Pendidikan, Penelitian dan Pengabdian. Universitas Pamulang (UNPAM) sudah mempunyai jaringan dengan berbagai lembaga lain yakni pemerintah pusat, pemerintah propinsi, pemerintah kabupaten, dunia usaha, swasta maupun dengan masyarakat.

Melihat lokasi kampus yang tidak jauh dengan lokasi Yayasan Kafilatur Rosul Pamulang - Tangerang Selatan - Banten, maka sudah menjadi kewajiban bagi Perguruan Tinggi untuk ikut serta membantu berbagai persoalan yang dihadapi oleh anak - anak asuhan dalam menangani persoalan pemecahan permasalahan dalam matematika dan peningkatan pemahaman protokol kesehatan demi membantu pemerintah mensosialisasikannya kepada masyarakat. Sudah selayaknya kehadiran perguruan tinggi agar dapat benar - benar dirasakan manfaatnya oleh masyarakat baik yang dekat maupun yang jauh.

Kegiatan pengabdian kepada masyarakat ini dilaksanakan selain berguna untuk anak binaan Yayasan Kafilatur Rosul Pamulang - Tangerang Selatan - Banten juga dapat dijadikan sebagai wadah pembelajaran bagi mahasiswa dalam memecahkan persoalan matematika dalam dunia nyata. Selain itu juga dapat dijadikan sebagai model atau metode pembelajaran yang dapat diterapkan di tempat mahasiswa suatu saat bekerja. Sehingga lebih mudah diterima penjelasannya ketika memecahkan persoalan yang berhubungan dengan matematika.

Program pengabdian ini disusun berdasarkan hasil survey pendahuluan oleh tim pengabdian kepada masyarakat ke lokasi Yayasan Kafilatur Rosul Pamulang Tangerang Selatan - Banten serta wawancara kepada pengurus yayasan tersebut demi membantu yayasan Kafilatur Rosul agar anak - anak binaannya dapat menjaga kesehatan selama pandemi COVID-19 dan dapat menjadi anak - anak yang cerdas di bidang matematika di sekolahnya. Kami dari Tim Program Pengabdian Kepada Masyarakat (PKM) Universitas Pamulang (UNPAM) yang berjumlah 5 orang dosen dan 4 orang mahasiswa ingin membantu dalam menyelesaikan persoalan pembelajaran matematika yang dihadapi oleh anak asuhan di Yayasan Kafilatur Rosul dan memberikan edukasi mengenai protokol kesehatan dengan judul PKM: "SEHAT DAN CERDAS DI MASA PANDEMI COVID-19 PADA YAYASAN KAFILATUR ROSUL PAMULANG TANGERANG SELATAN - BANTEN". 


\section{METODE PELAKSANAAN}

Alternatif pemecahan masalah dilakukan dengan memberikan pengetahuan serta bimbingan baik dalam pelajaran matematika kelas 1 SMP dengan materi aljabar dan himpunan maupun bimbingan dalam melakukan protokol kesehatan dalam masa pandemi COVID-19 di masa sekarang. Pembimbingan pemberian materi matematika dilakukan secara menyenangkan agar siswa dapat menerima materi pelajaran dengan lebih baik, serta diselingi dengan contoh - contoh penggunaan rumusan matematika dalam kehidupan sehari - hari sehingga siswa - siswi dapat mengetahui pentingnya ilmu matematika dalam kehidupan sehari - hari. Di masa pandemi, siswa - siswi juga perlu mengetahui penerapan protokol kesehatan yang baik dan benar demi mencegah penularan virus COVID-19 dan menjaga mereka agar tetap sehat dan dapat belajar dengan baik dari rumah.

Berdasarkan penjelasan pada pendahuluan analisis situasi di atas maka realisasi pemecahan masalah dalam pengabdian masyarakat ini antara lain:

1). Menyiapkan materi tentang contoh - contoh penggunaan atau penerapan ilmu matematika dalam kehidupan sehari - hari yang dekat dengan anak asuhan yayasan Kafilatur Rosul sehingga mereka memahami bahwa di segala aspek kehidupan pasti membutuhkan ilmu matematika, dengan demikian mereka akan lebih giat dalam belajar dan menuntut ilmu salah satunya adalah ilmu matematika

2). Menyiapkan materi matematika kelas 1 SMP tentang himpunan dan aljabar. Di dalam penyampaian materi akan diberikan cara cepat dan tepat dalam menyelesaikan persoalan tersebut sehingga anak asuhan yayasan Kafilatur Rosul dapat menggunakan cara tersebut dalam pembelajaran matematika di sekolahnya.

3). Menyiapkan materi tentang COVID-19 mulai dari asal muasal virus tersebut ada, gejala - gejala yang ditimbulkan jika kita terkena atau terinfeksi virus tersebut sampai dengan cara pencegahannya agar tidak tertular atau terjangkiti oleh virus tersebut dengan penerapan protokol kesehatan

Metode pelaksanaan yang dilakukan oleh TIM Pengabdian Kepada Masyarakat dalam pengabdian kepada masyarakat ini antara lain adalah sebagai berikut:

1). Pelaksanaan pengabdian kepada masyarakat ini dilaksanakan melalui 3 sesi antara lain : penyampaian materi edukasi kesehatan (cara mencuci tangan yang benar, cara memakai masker yang baik, aturan protokol kesehatan yang harus dilaksanakan dimana pun berada), penyampaian materi tentang pentingnya ilmu matematika dalam kehidupan sehari - hari (manfaat dan kegunaan ilmu matematika dalam kehidupan sehari - hari yang dekat dengan anak binaan Yayasan Kafilatur Rosul), dan penyampaian materi matematika kelas 1 SMP (materi matematika meliputi materi aljabar dan himpunan).

2). Kegiatan pengabdian kepada masyarakat ini juga harus mematuhi protokol kesehatan sehingga hanya 5 orang dari TIM pengabdian kepada masyarakat yang dapat hadir bertatap muka langsung dengan anak binaan sedangkan sisanya dilakukan secara online sehingga pelaksanaan pengabdian kepada masyarakat ini dilakukan dengan dua cara yaitu melalui daring (zoom) dan tatap muka secara langsung

3). Penyampaian materi yang dilaksanakan secara online atau daring (zoom) adalah penyampaian materi tentang pentingnya ilmu matematika dalam kehidupan sehari - hari dan edukasi kesehatan mengenai cara mencuci tangan yang benar, cara 
memakai masker yang baik, aturan protokol kesehatan COVID-19 di masa pandemi

4). Penyampaian materi yang dilaksanakan secara tatap muka langsung adalah penyampaian materi matematika kelas 1 SMP yaitu materi himpunan dan aljabar

5). Adapun waktu pelaksanaan pengabdian kepada masyarakat ini yaitu mulai hari Kamis 5 November 2020 sampai dengan Sabtu 7 November 2020 dengan perincian kegiatan sebagai berikut

Tabel 1 Jadwal Acara Pengabdian Kepada Masyarakat

\begin{tabular}{|c|c|c|c|c|}
\hline No & Waktu & Susunan Acara & Pemateri/Penanggung Jawab & Metode \\
\hline \multicolumn{5}{|c|}{ Kamis, 5 November 2020} \\
\hline 1 & $09.00-09.15$ & Pembukaan Acara & $\begin{array}{l}\text { MC (Yulis Setiani / Nanda Putri) - } \\
\text { Mahasiswa }\end{array}$ & $\begin{array}{l}\text { Zoom atau } \\
\text { Tatap Muka }\end{array}$ \\
\hline 2 & $09.15-09.30$ & Sambutan Ketua PKM & $\begin{array}{l}\text { Andi Nur Rahman, S.Si., M.Pd. - } \\
\text { Dosen }\end{array}$ & Tatap Muka \\
\hline 3 & $09.30-09.45$ & Sambutan Ketua Yayasan & Ustadz Ahmad Nawawi & Tatap Muka \\
\hline 4 & $09.45-10.45$ & $\begin{array}{l}\text { Penyampaian Materi Edukasi } \\
\text { Kesehatan (Protokol } \\
\text { Kesehatan COVID-19) }\end{array}$ & $\begin{array}{l}\text { NurulLita Sari, S.Pd., M.H. dan Nanik } \\
\text { Ida Rosini, S.H., M.H. - Dosen }\end{array}$ & $\begin{array}{l}\text { Zoom atau } \\
\text { Tatap Muka }\end{array}$ \\
\hline 5 & $10.45-11.00$ & Penutupan Acara & $\begin{array}{l}\text { MC (Yulis Setiani / Nanda Putri) - } \\
\text { Mahasiswa }\end{array}$ & $\begin{array}{l}\text { Zoom atau } \\
\text { Tatap Muka }\end{array}$ \\
\hline \multicolumn{5}{|c|}{ Jum'at, 6 November 2020} \\
\hline 1 & $09.00-09.30$ & kaan Acara & $\begin{array}{l}\text { MC (Mardianis / M. Amirudin) - } \\
\text { Mahasiswa }\end{array}$ & $\begin{array}{l}\text { Zoom atau } \\
\text { Tatap Muka }\end{array}$ \\
\hline 2 & $09.30-10.30$ & $\begin{array}{lr}\text { Penyampaian } & \text { Materi } \\
\text { Pentingnya } & \text { Matematika } \\
\text { Dalam Kehidupan } & \\
\end{array}$ & $\begin{array}{l}\text { Nunung Kusdaniyama, S.Si., M.Si., } \\
\text { Nina Valentika, S.Si., M.Si.- Dosen }\end{array}$ & $\begin{array}{l}\text { Zoom atau } \\
\text { Tatap Muka }\end{array}$ \\
\hline 3 & $10.30-11.00$ & upan Acara & $\begin{array}{l}\text { MC (Mardianis / M. Amirudin) - } \\
\text { Mahasiswa }\end{array}$ & $\begin{array}{l}\text { Zoom atau } \\
\text { Tatap Muka }\end{array}$ \\
\hline \multicolumn{5}{|c|}{ Sabtu, 7 November 2020} \\
\hline 1 & $09.00-09.15$ & ukaan Acara & $\begin{array}{l}\text { MC (Yulis Setiani / Nanda Putri) - } \\
\text { Mahasiswa }\end{array}$ & Tatap Muka \\
\hline 2 & $09.15-09.30$ & $\begin{array}{l}\text { Pre Test Materi Himpunan dan } \\
\text { Aljabar }\end{array}$ & $\begin{array}{l}\text { Mardianis dan Muchamad Amirudin - } \\
\text { Mahasiswa }\end{array}$ & Tatap Muka \\
\hline 3 & $09.30-11.00$ & $\begin{array}{lr}\text { Penyampaian } & \text { Materi } \\
\text { Himpunan dan Aljabar (Materi } \\
\text { Kelas 1 SMP) }\end{array}$ & $\begin{array}{l}\text { Andi Nur Rahman, S.Si., M.Pd. dan } \\
\text { Nina Valentika, S.Si., M.Si. }\end{array}$ & Tatap Muka \\
\hline 4 & $11.00-11.15$ & $\begin{array}{l}\text { Post Test Materi Himpunan } \\
\text { dan Aljabar }\end{array}$ & Mardianis dan Muchamad Amirudin & Tatap Muka \\
\hline 5 & $11.15-11.30$ & Pembagian Hadiah & Andi Nur Rahman - Dosen & Tatap Muka \\
\hline 6 & $11.30-12.00$ & Penutupan Acara & $\begin{array}{l}\text { MC (Yulis Setiani / Nanda Putri) - } \\
\text { Mahasiswa }\end{array}$ & Tatap Muka \\
\hline
\end{tabular}

\section{HASIL DAN PEMBAHASAN}

Secara umum kegiatan pengabdian kepada masyarakat ini yang dilakukan melalui penyuluhan kesehatan dan bimbingan belajar matematika ini berjalan dengan baik dan lancar, peserta terdiri dari anak - anak binaan Yayasan Kafilatur Rosul yang sangat antusias dalam mengikuti kegiatan ini. Mereka jadi lebih mengetahui cara mencuci tangan yang baik dan benar, memakai masker dan menjaga jarak jika berada di luar rumah, serta adanya peningkatan kemampuan matematis siswa dibandingkan dengan 
sebelum adanya bimbingan dari Tim pengabdian kepada masyarakat, hal ini disebabkan karena pemberian materi dilakukan dengan cara yang menyenangkan dan mudah dipahami oleh siswa.

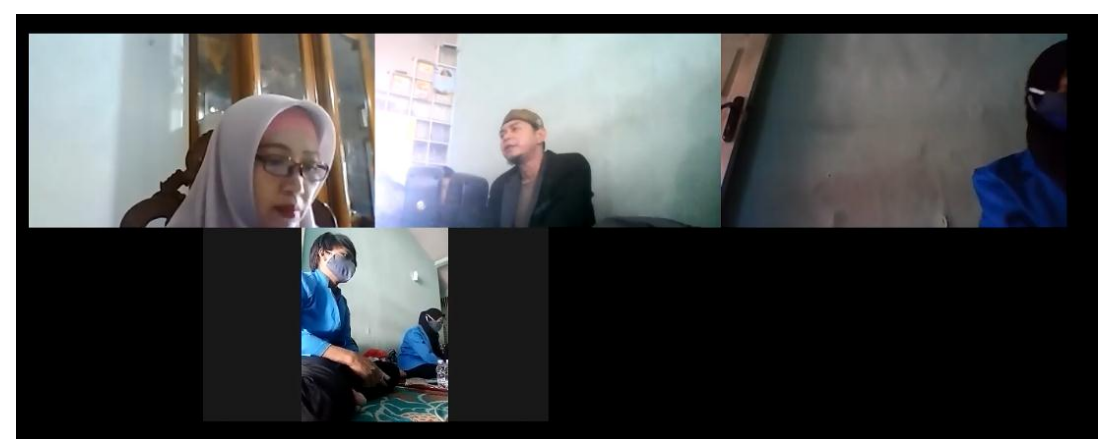

Gambar 1 Acara Pembukaan

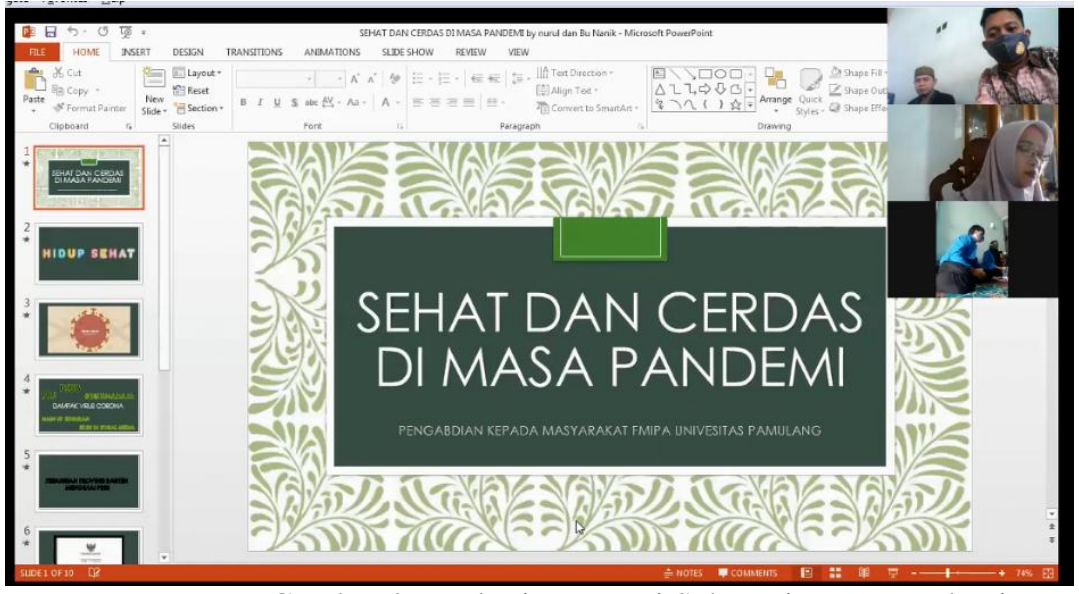

Gambar 2 Pemberian Materi Sehat Di Masa Pandemi

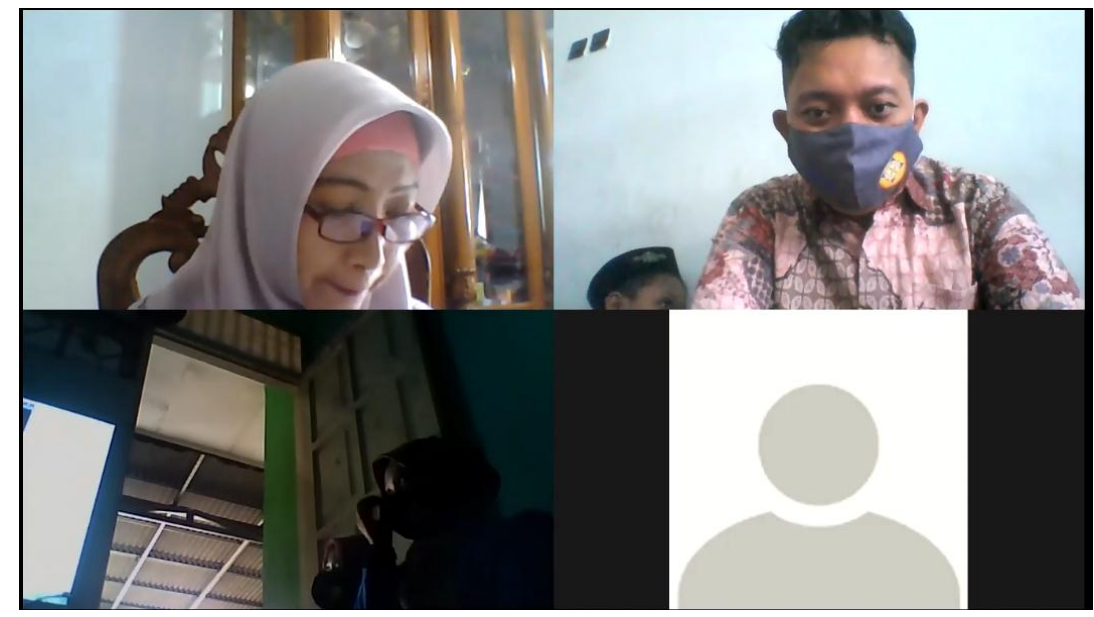

Gambar 3 Pemberian Materi Pentingnya Matematika 
Sehat Dan Cerdas Di Masa Pandemi COVID-19 Pada Yayasan Kafilatur Rosul Pamulang Tangerang Selatan - Banten

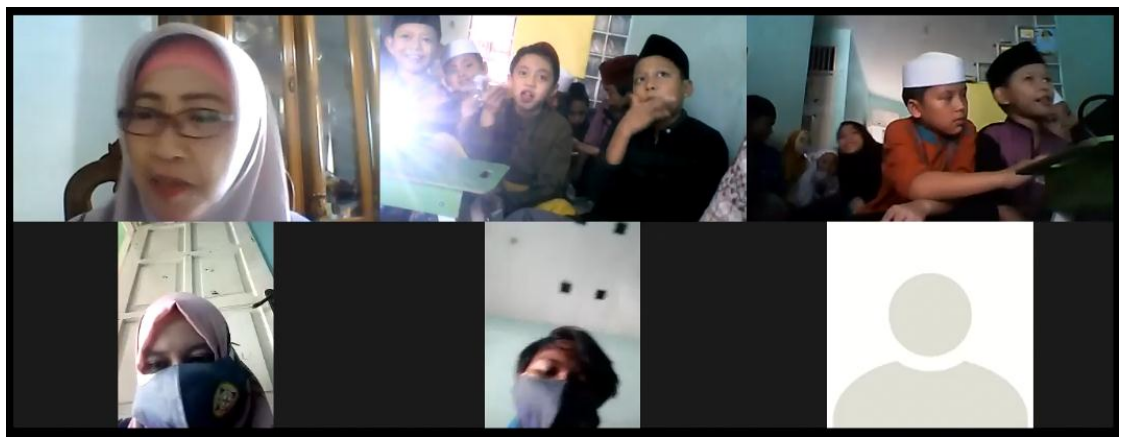

Gambar 4 Pretest Materi Matematika

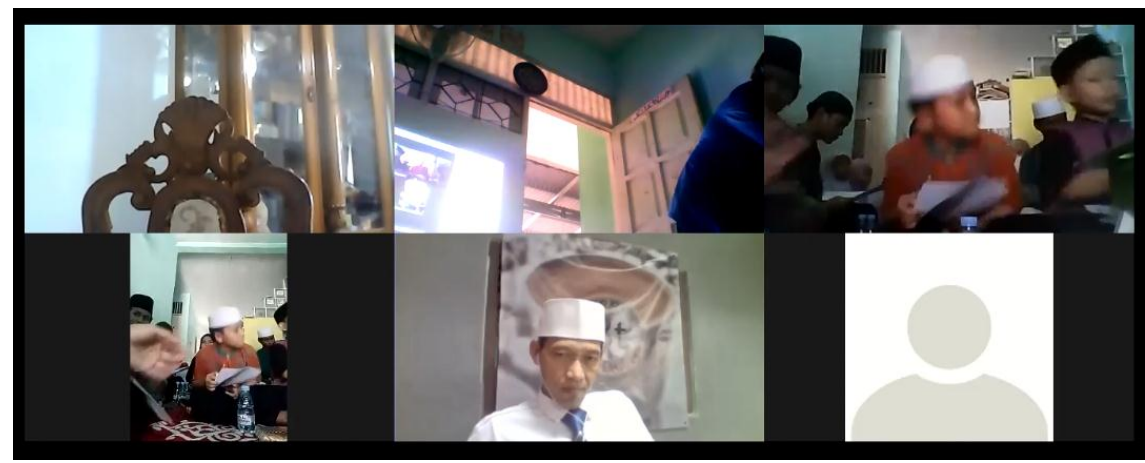

Gambar 5 Bimbingan Materi Matematika

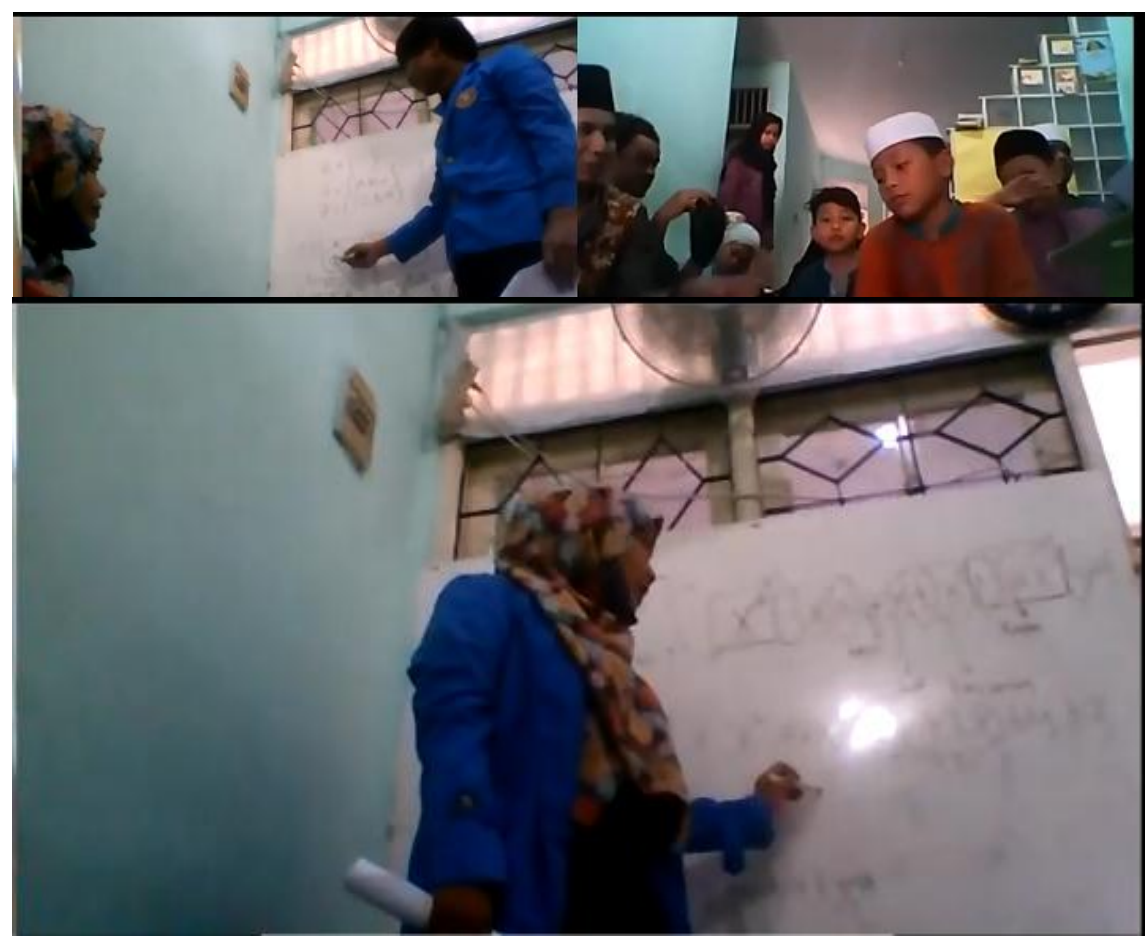

Gambar 6 Penjelasan Materi Matematika 


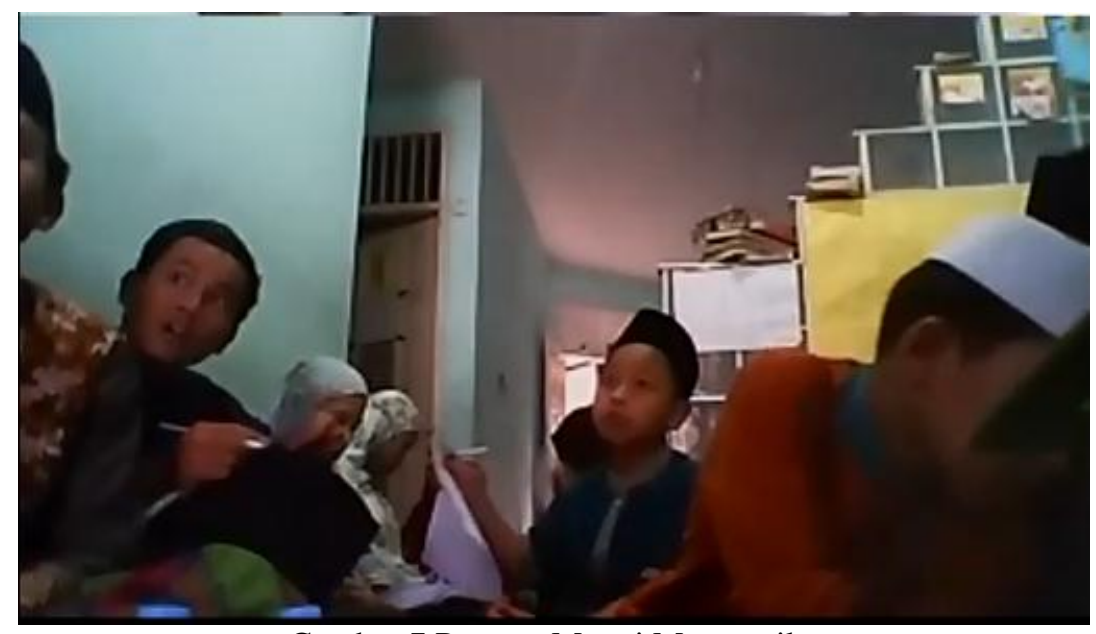

Gambar 7 Posttest Materi Matematika

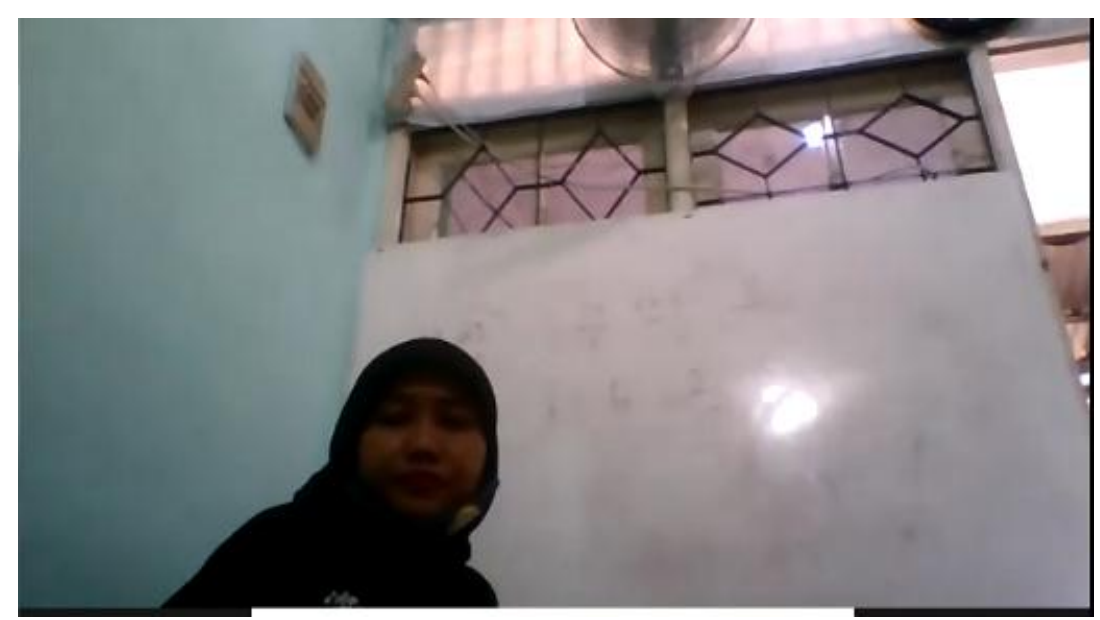

Gambar 8 Acara Penutupan

\section{SIMPULAN}

Pentingnya hidup sehat di masa pandemi dengan menerapkan protokol kesehatan yang baik dan benar yaitu Mencuci tangan, Memakai masker, dan Menjaga Jarak agar kita terhindar dari COVID-19, hal tersebut penting untuk diketahui dan dipahami oleh generasi penerus bangsa agar bangsa Indonesia memiliki generasi penerus yang sehat fisik, jasmani dan rohani. Pentingnya matematika dalam kehidupan dengan mengetahui penggunaan atau aplikasi matematika di dalam kehidupan sehari - hari dapat membantu siswa agar dapat minimal menyukai mata pelajaran matematika sehingga mereka dapat belajar matematika dengan giat dan tekun. Selain itu untuk meningkatkan motivasi dan minat belajar mereka diperlukan metode pengajaran matematika yang menarik, menyenangkan dan mudah untuk mereka pahami, hal ini ditunjukkan dari peningkatan hasil evaluasi pretest ke posttest setelah dilakukan pemberian materi dengan menarik, menyenangkan dan mudah untuk dipahami oleh para siswa.

Adapun saran dari hasil pengabdian kepada masyarakat ini adalah selalu mengingatkan anak - anak akan bahayanya COVID-19 dan selalu menerapkan protokol kesehatan yang baik dan benar di mana pun berada, sedangkan untuk para pengajar 
Sehat Dan Cerdas Di Masa Pandemi COVID-19 Pada Yayasan Kafilatur Rosul Pamulang Tangerang Selatan - Banten

khususnya pengajar matematika untuk dapat mengajar materi matematika dengan menarik, menyenangkan dan mudah dipahami oleh siswa.

\section{DAFTAR PUSTAKA}

Agung, Lukito, dan Sisworo. 2014. Matematika: Kelas VII SMP/MTs. Edisi Revisi. Jakarta: Pusat Kurikulum dan Perbukuan, Balitbang, Kemdikbud.

Kementerian Kesehatan. 2020. COVID-19.

http://www.padk.kemkes.go.id/article/read/2020/04/23/21/hindari-lansia-daricovid-19.html. Diakses pada tanggal 28 Oktober 2020

Munir, Rinaldi. 2010. Matematika Diskrit. Revisi Keempat. Bandung: Informatika Bandung

Wikipedia. https://id.m.wikipedia.org/wiki/Himpunan_(matematika) 